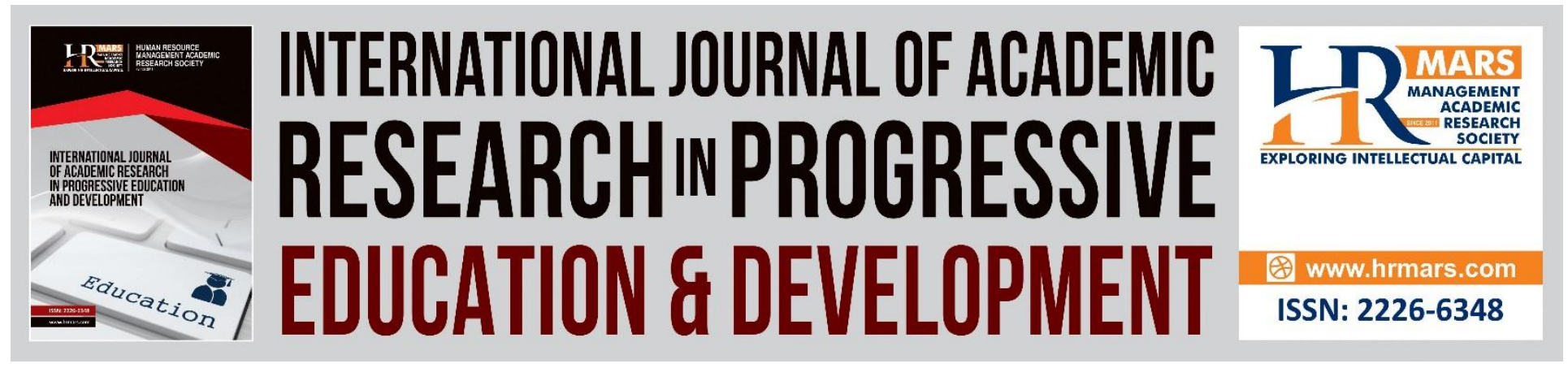

\title{
The Suitability of Reading Skills in Malay Language Curriculum for the Indigenous and the Implementation among Malay Language Teachers
}

\author{
Mohamad Nik Mat Pelet, Jamaludin Badusah
}

To Link this Article: http://dx.doi.org/10.6007/IJARPED/v7-i3/4573

DOI: $10.6007 /$ IJARPED/v7-i3/4573

Received: 26 May 2018, Revised: 18 June 2018, Accepted: 13 July 2018

Published Online: 28 July 2018

In-Text Citation: (Pelet \& Badusah, 2018)

To Cite this Article: Pelet, M. N. M., \& Badusah, J. (2018). The Suitability of Reading Skills in Malay Language Curriculum for the Indigenous and the Implementation among Malay Language Teachers. International Journal of Academic Research in Progressive Education and Development, 7(3), 549-556.

\section{Copyright: (C) 2018 The Author(s)}

Published by Human Resource Management Academic Research Society (www.hrmars.com)

This article is published under the Creative Commons Attribution (CC BY 4.0) license. Anyone may reproduce, distribute, translate and create derivative works of this article (for both commercial and non-commercial purposes), subject to full attribution to the original publication and authors. The full terms of this license may be seen

at: http://creativecommons.org/licences/by/4.0/legalcode

Vol. 7, No. 3, July 2018, Pg. 549 - 556

http://hrmars.com/index.php/pages/detail/IJARPED

JOURNAL HOMEPAGE

Full Terms \& Conditions of access and use can be found at http://hrmars.com/index.php/pages/detail/publication-ethics 


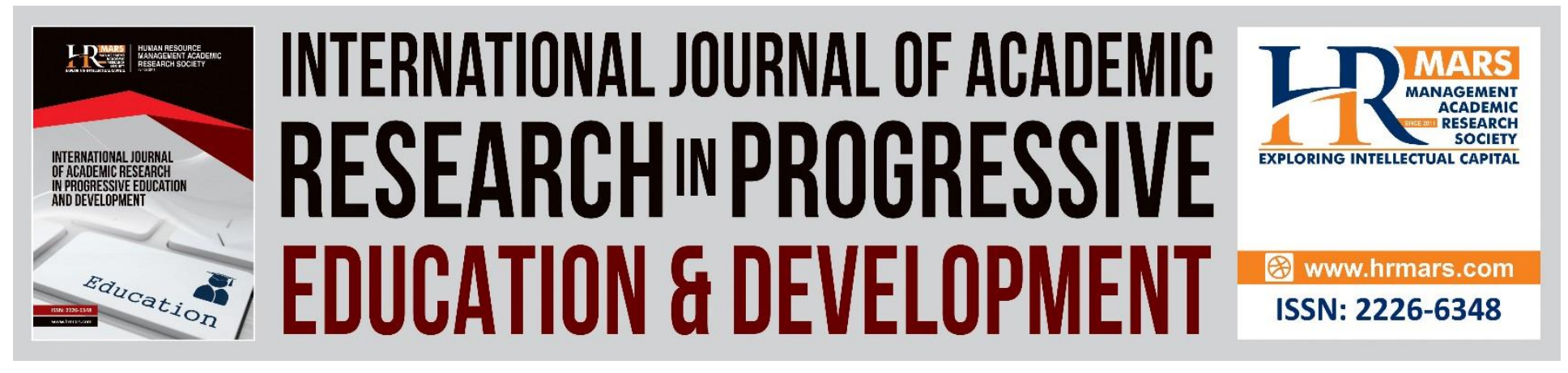

\title{
The Suitability of Reading Skills in Malay Language Curriculum for the Indigenous and the Implementation among Malay Language Teachers
}

\author{
Mohamad Nik Mat Pelet \\ National University Of Malaysia, Malaysia \\ Email: niktpelet@yahoo.com \\ Jamaludin Badusah \\ National University Of Malaysia, Malaysia
}

\begin{abstract}
This study aims to explore the perceptions of Malay language teachers in the schools with Orang Asli pupils, in relation to the suitability of reading skills in Malay language drafted in Penan Asli Curriculum (PAC) and its implementation among Malay language teachers in the schools. This qualitative case study involves five research participants selected through a purposive sampling from three schools of indigenous people in Pahang, Malaysia. The data for this study was collected through semi-structured interview, observation during Teaching and Learning (T\&L) and document analysis which was also being analysed using Nvivo12 software. The collected data was analyzed descriptively and presented in narrative form. The findings showed that the reading skills in Malay language in PAC are effective for T\&L in indigenous classroom as it caters to the needs of indigenous pupils in terms of the inclusion of their background elements and the number of simplified as wel as gradually constructed skills. The findings also found that the implementation of PAC Malay reading skills were inconsistent as the teachers were focused on the Malay language reading skills in Primary School Curriculum (KSSR) and Literacy and Numeracy (LINUS) instruments. At the end of the study, a T\&L model of Malay language PAC reading skills has been proposed to improve the implementation, as well as the Orang Asli pupils' mastery and achievement in reading skills.
\end{abstract}

Keywords: Reading Skills, Penan Asli Curriculum (PAC), Malay Language, Indigenous Pupils, Teaching and Learning (T\&L)

\section{Introduction}

The Orang Asli community in Malaysia is a group of indigenous people who is less exposed especially in terms of services, education and health. The indigenous peoples live mostly 
INTERNATIONAL JOURNAL OF ACADEMIC RESEARCH IN PROGRESSIVE EDUCATION AND DEVELOPMENT

Vol. 7, No. 3, July 2018, E-ISSN: 2226-6348 @ 2018 HRMARS

in remote areas where it is difficult for them to have access to any services provided by the government. This situation has caused the Orang Asli to remain left behind and thus, neglect the importance of education as they thought it holds no impact on their lives.

However, the Malaysian government through the Ministry of Education Malaysia (MOE) has taken the initiative by channelling various assistance including providing infrastructures such as school buildings, basic schooling needs, financial aid for education, clothing and dormitories in order to facilitate and provide an effective education system for them. This initiative is carried out to produce quality human capitals including Orang Asli communities by ensuring that they are competent in terms of physical, emotional, spiritual and intellectual aspects as emphasized in National Education Philosophy (FPK).

\section{Penan Asli Curriculum:}

In March 2007, a pilot of the Penan Asli Curriculum (PAC) was introduced which involved a number of Orang Asli schools in several states in Malaysia such as Pahang, Kelantan, Perak, Selangor and Negeri Sembilan. The PAC is the result from the Committee Meeting Addressing Orang Asli and Penans Education Issues No. 3/2006 dated 18 October 2006. The outcome of the meeting found the need to revise the curriculum adopted at Orang Asli schools. The curriculum review involves several aspects such as the needs, experience and environment relevant to the sociocultural community of the Orang Asli. The PAC also emphasizes three fundamental skills in Malay language subject i.e. oral, reading and writing skills.

Modular learning was introduced at the PAC pilot stage. The Curriculum Development Division (BPK) which has been given the responsibility to realize the implementation of the PAC has made changes with regard to the implementation of the earlier Integrated Primary School Curriculum (KBSR) before it was being replaced by the current Standard Primary School Curriculum (KSSR) which is in use by other national schools. It aims to ensure that the curriculum is able to produce competitive Orang Asli pupils and in tandem with other societies.

The implementation of PAC in 2009 has been empowered by targeting the schools of Orang Asli that did not perform well in terms of academic achievement in the public examination, Primary School Assessment Test (UPSR). Out of the 93 Orang Asli schools in Malaysia, 36 schools were instructed to use PAC as a measure to enhance the mastery of Orang Asli students and to boost their academic achievement (Ramlah 2009).

\section{Statement of Problem}

Academic achievement of Orang Asli pupils is still poor due to various factors including unsuitable curriculum for teaching (Norwaliza 2014). Along with that, Aminuddin (2017) also recommended a more suitable curriculum implementation in terms of socio-culture and the Orang Asli community's environment to enhance their mastery and achievement. Ganal (2017) also mentioned the need to provide a special curriculum for Orang Asli communities in the Philippines. Abayoa (2014) also supported the efforts to review the curriculum used in the teaching and learning of the Orang Asli community by applying the background of the Orang Asli community both local and abroad. This effort was made to improve the academic background of the Orang Asli community and thus create a community that is competitive as well as other communities in Malaysia. 
Vol. 7, No. 3, July 2018, E-ISSN: 2226-6348 @ 2018 HRMARS

\section{The Framework Concept Studied}

This study involved teaching theory and model. The selection of the Bottom-Up reading theory is a theory synonymous with reading learning among Orang Asli pupils. Bottom-Up Theory emphasizes reading progress in stages ranging from basic skills to the ability to understand the whole reading text. Meanwhile, Model Robert Glaser (1962) and Model Sim are the teaching models that can serve as a guide to Malay language subject teachers to carry out more effective teaching and learning process.

\section{Objective}

The purpose of this study was to explore more about Malay language reading skills in PAC. In general, the objective of this study is to:

i. Explore the suitability of Malay language reading skills in PAC from the point of view of the Malay language teachers in Orang Asli schools.

ii. Examine the implementation by the Malay language teachers at Orang Asli schools in relation to PAC Malay language reading skills.

\section{Methodology}

This qualitative study requires researchers to have better insight of the explored phenomena. The selection of qualitative study provides space for researchers to carry out an in depth and meaningful research in each scope related to research phenomena (Gall et al. 2007 \& Meriamm 2009). The study conducted at three Orang Asli schools in Pahang involves five Malay language teachers. Teachers were selected through purposive sampling by taking into account the participants that represent the study's population (Celinea 2018). Ghazali and Sufean (2016) stated that the number of small study participants between one and seven is sufficient to obtain the study data. Similarly, Noraini (2013) also explained the number of small study participants capable of providing in-depth and effective data analysis. Researchers used interviews, observations and analyzes of documents in obtaining data to answer this research question. Norhayati (2012), Othman (2015) and Celinea (2018) described the interview instrument as a set of questions based on the objective of the study to help researchers obtain accurate and relevant data. Marshall and Rossman (2014) emphasized the use of observation instruments as a researcher's opportunity to record more in-depth data to support the findings of the study while Besh and Kahn (2003) stated that the use of document analysis instruments can help researchers to create more structured data records and focusing.

\section{Result and Discussion}

Based on the interviews, observations and analysis of documents that have been conducted, the findings of this study can be described as the following description:

\section{Question 1: The suitability of Malay reading skills in PAC}

Based on the interviews, the five participants stated that reading skills in Malay language in PAC are appropriate for the teaching and learning of Orang Asli pupils. Meanwhile, KSSR, the previous curriculum adopted at the Orang Asli schools, the skills found therein are not in accordance with the Orang Asli community. The findings of data relating to the suitability of Malay reading skills contained in PAC can be explained as follows: 
Vol. 7, No. 3, July 2018, E-ISSN: 2226-6348 @ 2018 HRMARS

\section{i. Application of native perspective}

The participants of the study mentioned that the adoption of the indigenous people's perspectives in terms of community, socio-cultural, environmental, symbol and image related to the Orang Asli community and their practice is emphasized in PAC for learning Malay Language reading skills. The findings of the observation data showed that the application of these elements facilitates the Orang Asli pupils' comprehension in reading. It helped them to understand the lessons learned as they able to relate directly to their lives and environment. In the meantime, the application of this native perspective also aims to increase their control and interest in education. In addition, the application of this native perspective can be clearly seen in the curriculum document supplied to every Orang Asli schools.

\section{ii. Number of reading skill reduced}

The findings also show that the number of reading skills in Malay language PAC has been reduced to six skills. They need to be mastered during Year One and 12 reading skills should be studied during Year Two and Year Three whereas KSSR emphasizes the mastery of 16 skills for pupils in Year One. The number of reading skills in KSSR makes it difficult for students to master the skills because of their limited ability in reading skills (Md. Nasir et al., 2010). According to the participants, the reduction in the number of reading skills that must be learned and mastered by Orang Asli pupils can enhance their reading comprehension. This statement can be proven in the observation results during teaching and learning conducted by the Malay language teachers. Pupils responded positively when questioned by the teachers during teaching reading skills as compared to the previous situation when KSSR was in use. According to Ramlah (2009), the use of inappropriate curriculum would not only affect students' interest in academics but also has a constant impact on their assumptions about a particular subject.

\section{iii. Application of progressive reading skills}

The researchers also found that the application of reading skills in Malay language emphasized in the PAC is devised in stages according to school year. Based on the interviews with the participants, they explained that the basic reading skills are emphasized in Year One while higher skills will be introduced when pupils are in Year Two and Year Three. This implementation has made it easier for the pupils to master every skill from basic to high level of reading skills. Furthermore, from the document analysis, researchers found that basic skills were emphasized in each year of learning while higher reading skills were emphasized by school year as compared to previous curriculum namely KSSR which emphasized high reading skills level from Year One. The previous situation had affected the interest of Orang Asli pupils in learning as they are still struggling in mastering the skills. They became demotivated to learn reading skills in particular.

\section{Question 2: The Implementation Of Malay reading skill in PAC}

Based on the interviews, the researchers found that the implementation of Malay language reading skills available in the PAC is inconsistent and persistent throughout the school year. This finding is supported by the data from document analysis and through observation carried out during the teaching and learning session conducted by the Malay Language teachers at the Orang Asli schools. The description of the question 2 of this study can be concluded as follows: 


\section{i. Implementation of the first three months of schooling between January and March}

Based on interviews with the participants, researchers found that the teachers of Malay language in Orang Asli schools only managed to carry out the reading skills for the first three months of schooling between January and March each year. This situation is due to the fact that Malay language teachers are needed to focus on the implementation of other programs such as Literacy and Numeracy (LINUS) programs even though their main focus should be in the implementation of teaching based on the curriculum rather than the academic program. This situation occurs every year due to the overlapping instructions issued by the responsible party to ensure that academic programs are carried out and for this reason the focus of the teachers is on LINUS instead of PAC.

This finding is confirmed by the analysis of the daily lesson plan of the Malay language teachers. The analysis showed that the production of PAC-based daily lesson plans is only implemented until March. From April to November, researchers found that Malay language teachers used other curriculum other than PAC such as KSSR and materials from the LINUS program. As a result, pupils did not only failed to master the reading skills contained in the PAC but also the implementation of KSSR-based teaching and LINUS materials did not achieve the target as expected by the Malay language teachers in their daily lesson plans.

\section{ii. The implementation by Malay language teachers focuses on reading skills in KSSR}

The researchers also found that Malay language teachers in Orang Asli schools had regularly implemented the teaching of Malay-language reading skills based on KSSR rather than PAC. It becomes their preference for teaching reading even though the reading skills in KSSR are high level. The reason given is that it is easier for them to get materials related to the skills that been taught compared to obtaining materials suitable for PAC Malay reading skills. Based on the analysis of the daily lesson plans, Malay language teachers often make KSSR reading skills as the main objective in their daily lesson plans. However, through observation, pupils cannot understand the lesson yet the teachers choose to continue teaching reading skills based on KSSR.

\section{Conclusion}

A study focusing on the suitability of reading skills in PAC has proven that the reading skills are appropriate and relevant for the teaching and learning at Orang Asli schools. The devised reading skills in PAC have taken into account the perspective of indigenous peoples. This element is important to improve the mastery and understanding of pupils in relation to the skills that been taught (Rosli et al., 2009). Furthermore, the number of Malay reading skills in PAC has also been reduced to ensure that Orang Asli learners can learn more effectively and enhance their understanding. Ramlah (2009) also stated that Orang Asli pupils could not learn too much skill at one time, besides their slow development compared to other students (Wan Afizi et al., 2010). The application of PAC Malay reading skills which being introduced gradually also help Orang Asli pupils to focus more. The Malay reading skills that have been structured and graded gradually from basic to higher levels has make it easier for Orang Asli pupils to understand the concept of reading skills (Ramlah 2009). This is strongly supported by Mohd Kamal and Ab. Rahman (2009) stating that the need for Orang Asli pupils to learn reading skills progressively is to ensure that they are able to align what have been taught and learnt, with their prior knowledge. 
Vol. 7, No. 3, July 2018, E-ISSN: 2226-6348 @ 2018 HRMARS

However, the implementation of PAC Malay reading skills is inconsistent and persistent among Malay language teachers in Orang Asli schools. Malay language teachers in Orang Asli schools would rather refer to and use the Malay reading skills in KSSR as well as other resources such as support materials for the LINUS program. This is because the Malay language teachers think it is easier for them to have access to teaching materials if their teaching is based on KSSR and LINUS although the two sources do not match the level of their pupils. Inconsistent implementation does not only causes pupils failed to master the reading skills of Malay language but also made the pupils lost interest in the subject (Rosli et al., 2009).

Therefore, this situation must be addressed properly so that the Malay language teachers in Orang Asli schools can implement the PAC consistently as it is found suitable and relevant for the Orang Asli pupils since there is an element of application based on the native perspective, the number of skills and the progressive learning. The Malay language teachers in Orang Asli pupils also need to implement appropriate teaching and learning based on theories and models so that they can ensure that their implementation is in accordance with the Orang Asli pupils.

\section{Model of teaching and learning Malay language in PAC}

Chart 1: Model of teaching and learning reading skills in Malay language in PAC

Model Robert Glaser
- Teaching objectives, prior knowledge, teaching
procedure and assessment

\begin{tabular}{|c|} 
Progressive reading activities \\
\hline Mastery of reading skills in Malay language in PAC \\
\hline
\end{tabular}

\section{References}

Abayao, L. (2014). The Philippines indigenous peoples' core curriculum. UP Forum. Retrieved from http: // www.up.edu.ph/the-philippines-indigenous-peoples- core-curriculum/.

Aminuddin M. ( 2017). KEDAP Sustainability in the Human Capital Development of the Orang Asli. Thesis Thesis Fal. Institute of Environment and Development, National University of Malaysia, Bangi.

Best, J. W., \& Kahn, J. V. (2003). Research in education (9th Ed.) Boston: Allyn and Bacon.

Celinea L. (2018). Practice of Learning Malay Language Skills in Bidayuh Pupils. Thesis Thesis Fal. Faculty of Education, Universiti Kebangsaan Malaysia, Bangi.

Ganal, N. (2017). The University of Ottawa Indigenous Peoples Education Curriculum Model: Basis in the Development of Indigenous Peoples Education Curriculum for PNU-North Luzon. The Normal Lights, 11 (1), 198 - 234.

Ghazali D. \& Sufean H. (2016). Research Methodology in Education. Kuala Lumpur: University of Malaya Publisher.

Marshall, C., \& Rossman, G.B. (2014). Designing qualitative research. 6th Edition. Thousands Oaks, California: SAGE Publications Inc. 
INTERNATIONAL JOURNAL OF ACADEMIC RESEARCH IN PROGRESSIVE EDUCATION AND DEVELOPMENT

Vol. 7, No. 3, July 2018, E-ISSN: 2226-6348 @ 2018 HRMARS

Md. Nasir, M., Ramlah, J., Suppiah, N., Abd. Aziz S. \& Roslinda M. (2010). Stages of readability among Orang Asli students (Rehabilitation Program) at Brinchang National School (Pahang) and Sekolah Kebangsaan Batu 14, Tapah (Perak). Papers are presented in the JPPG Seminar. Universiti Kebangsaan Malaysia.

Merriam, S. B. (2009). Qualitative Research: A Guide to Design and Implementation, Revised and Expanded From Qualitative Research and Case Study Applications in Educations. San Francisco: Jossey-Bass.

Mohd Kamal, M. A. \& Ab. Rahman M. (2009). Use of local knowledge to improve the mastery of reading and writing skills at Orang Asli Schools. In Abdul Razaq Ahmad \& Zalizan Mohd Jelas (pnyt.). Orang Asli: Perspective of education and socio-cultural, p. 89-98. Bangi: Faculty of Education, Universiti Kebangsaan Malaysia.

Noraini, I. (2013). Research in Education. Selangor: McGraw-Hill Education (M) Sdn. Bhd.

Norhayati, M. N. ( 2012). Family Counseling Process Among Family Counseling Practices In Malaysia. Thesis Thesis Fal. National University of Malaysia, Bangi.

Othman, L. (2015). Qualitative Research: Introduction to Theory and Method. Publisher University Pendidi of Sultan Idris, Tanjong Malim

Ramlah, A. R. (2009). Integrated Curriculum Pilot Project of Orang Asli and Penan Students. A pilot study. IPGMKTAA.

Rosli, Y., Zahedah, A. H. \& Lokman ,A. W. (2009). Joint learning and effective practice of indigenous pedagogy Native-Penan curriculum: A case study. In Abdul Razaq Ahmad \& Zalizan Mohd Jelas (pnyt.). Indigenous peoples: Educational and socio-cultural perspectives, p. 77-89. Bangi: Universiti Kebangsaan Malaysia.

Wan Afizi, W. H., Shaharuddin, A. \& Noraziah, A. (2014). Cultural and environmental factors in Malaysia's Orang Asli children's educational performance: Case study in Kelantan. Center for Social Studies, Development and Environment, Faculty of Social Science and Humanities, National University of Malaysia. 